\title{
GOMMENT
}

\section{COERGION, BLACKMAIL, AND THE LIMITS OF PROTECTED SPEECH}

The Oregon Supreme Court recently reviewed the constitutionality of that state's criminal coercion statute. ${ }^{1}$ The Oregon statute made it a felony to induce a person to sacrifice any legal right by threatening to engage in certain types of conduct. A threat such as "Vote Republican or I will burn your house down" fell within the statute's proscription. In an opinion by Judge Linde, the court in State $v$. Robertson ${ }^{2}$ struck down the Oregon criminal coercion statute as an abridgement of free speech. ${ }^{3}$ The invalidated statute bore a striking resemblance to the typi-

2 OR. Rev. Stat. \& 163.275 (1981). The statute provides:

(1) A person commits the crime of coercion when he compels or induces another person to engage in conduct from which he has a legal right to abstain, or to abstain from engaging in conduct in which he has a legal right to engage, by means of instilling in him a fear that, if the demand is not complied with, the actor or another will:

(a) Cause physical injury to some person; or

(b) Cause damage to property; or

(c) Engage in other conduct constituting a crime; or

(d) Accuse some person of a crime or cause criminal charges to be instituted against him; or

(e) Expose a secret or publicize an asserted fact, whether true or false, tending to subject some person to hatred, contempt or ridicule; or

(f) Cause or continue a strike, boycott or other collective action injurious to some person's business, except that such a threat shall not be deemed coercive when the act or omission compelled is for the benefit of the group in whose interest the actor purports to act; or

(g) Testify or provide information or withhold testimony or information with respect to another's legal "claim or defense; or

(h) Use or abuse his position as a public servant by performing some act within or related to his official duties, or by failing or refusing to perform an official duty, in such manner as to affect some person adversely; or

(i) Inflict any harm which would not benefit the actor.

(2) Coercion is a Class C felony.

For a comparable coercion statute, see Model Penal Code § 212.5 (1980).

2293 Or. 402, 649 P.2d 569 (1982).

3 The holding in Robertson is based solely on the Oregon Constitution. Differences between Oregon free speech interpretations and federal interpretations are beyond the scope of this Comment. The Robertson analysis relevant to this Comment follows principles of free speech applicable to federal constitutional analysis. For a compilation of recent sources on state constitutional litigation and its import, see Devel- 
cal blackmail statute, ${ }^{4}$ which proscribes the use of threats to obtain the property of others. "Pay me $\$ 5000$ or I will burn your house down" is an example of restricted blackmail speech. The Robertson court suggested that it would have reached a different conclusion had it been required to pass upon the constitutionality of a blackmail statute."

Judge Linde noted that "[j]udicial and academic analyses of the principles governing freedom to make demands coupled with threats have been sparse and inconclusive . . . yield[ing] no principled guidance." Nevertheless, he had "no doubt" that blackmail statutes would survive first amendment scrutiny on "historic grounds alone." In striking down the criminal coercion statute, however, he explained that '[w]hen extending an old crime to wider 'subjects' . . . there is need for care that the extension does not leave its historical analogue behind and ... reach instances of privileged expression."s

This Comment argues that Judge Linde was correct to conclude both that first amendment principles restrict the scope of criminal coercion statutes and that blackmail statutes may constitutionally reach further than criminal coercion statutes. Part I sets forth the permissible scope of a criminal coercion statute. In Part II, this Comment proffers

opments in the Law-The Interpretation of State Constitutional Rights, 95 HARv. L. REv. 1324, 1328 n.20 (1982).

- See, e.g., Model Penal Code $\$ 223.4$ (1980). The statute provides:

A person is guilty of theft if he purposely obtains property of another by threatening to:

(1) inflict bodily injury on anyone or commit any other criminal offense; or

(2) accuse anyone of a criminal offense; or

(3) expose any secret tending to subject any person to hatred, contempt or ridicule, or to impair his credit or business repute; or

(4) take or withhold action as an official, or cause an official to take or withhold action; or

(5) bring about or continue a strike, boycott or other collective unofficial action, if the property is not demanded or received for the benefit of the group in whose interest the actor purports to act; or

(6) testify or provide information or withhold testimony or information with respect to another's legal claim or defense; or

(7) inflict any other harm which would not benefit the actor.

It is an affirmative defense to prosecution based on paragraphs (2), (3) or (4) that the property obtained by threat of accusation, exposure, lawsuit or other invocation of official action was honestly claimed as restitution or indemnification for harm done in the circumstances to which such accusation, exposure, lawsuit or other official action relates, or as compensation for property or lawful services.

- See 649 P.2d at 581 .

- Id. at 587.

Id. at 581 .

- Id. at 589. 
commercial speech doctrine rather than history as a justification for permitting legislatures greater leeway in enacting blackmail statutes.

\section{Coercive Speech}

"Coercive speech"- speech forcing the listener to choose between two things when the listener has a legitimate claim to both things-should fall outside the protections of the first amendment. While this concept permits legislatures to enact both criminal coercion and blackmail statutes proscribing some threats, it does not justify such statutes that operate in other areas.

\section{A. The Unprotected Nature of Coercive Speech}

Speech is protected generally not only because it promotes certain essential values, ${ }^{9}$ but also because it operates to promote those values in a particular way. ${ }^{10}$ Protected speech "create[s] an effect by influencing the mind-the perceptions, feelings, beliefs or understandings-of the listener." 11 Other activities, though they may advance the same values as does speech, do so by other means. For example, some could find self-fulfillment by forcing others to dance through the use of gunfire, and some could work toward social change by assassinating political leaders. Because of the means used to achieve these valued ends, however, these activities are not protected.

Like unprotected activity, speech that forces the listener to choose between two things, both of which the listener has a right to claim-"coercive speech"12 - acts on the listener in a different way from protected speech. ${ }^{13}$ As Professor Baker has argued, speech that

- Professor Emerson provides a description of these values. He notes that "a system of free expression" serves "(1) as assuring individual self-fulfillment, (2) as a means of attaining the truth, (3) as a method of securing participation by the members of society in social, including political, decision-making, and (4) as maintaining the balance between stability and change in the society." Emerson, Toward a General Theory of the First Amendment, 72 YaLe L.J. 877, 878-79 (1963). Professor Baker believes that Emerson's list boils down to two central free speech values, individual selffulfillment and participation in change. Baker, Scope of the First Amendment Freedom of Speech, 25 UCLA L. REv. 964, 991-92 (1978).

${ }_{10}$ See generally Baker, supra note 9, at 997-1009.

11 Id. at 997 (parenthetical omitted).

12 Scholars who have considered the concept of coercion differ as to the meaning of the term. Compare Nozick, Coercion, in PHILosophy, ScIENCE, AND METHOD -EsSAYS IN Honor of ERNEST NAgel 440 (1969) with Frankfurt, Coercion and Moral Responsibility, in Essays on FrEedom of Action 63 (T. Honderich ed. 1973) and McGloskey, Coercion: Its Nature and Significance, 18 S.J. PHIL. 335 (1980).

13 For the purposes of this analysis, a listener's legitimate rights are regarded as identical to the listener's legal rights. 
purposely changes another's options "such that the other is worse off than he would be if he had the options that he had a . . . legitimate right to expect"14 should not be protected by the first amendment. Such speech purposely forces a choice by resort to actual or apparent power over the listener. To the extent the speaker has the power to force the choice, coercive speech operates as illegitimate compulsion. If the speaker lacks such power but purposely uses apparent power to force the choice, this speech, too, operates as illegitimate compulsion.

Speech that forces a choice the listener would prefer not to make is not coercive simply because it manipulates the listener's options to his detriment, however. The issue is whether the speech actually reduces a listener's legitimate options. For this reason, speech with the purpose of forcing a listener's choice between two things, where the listener has a legitimate right to only one (or none) of the things, makes the listener no worse off than he has a legitimate right to expect. The speech thus does not have the same impact on the listener's autonomy as coercive speech does and therefore should be protected because of its potential benefit to the speaker. ${ }^{16}$

\section{B. Regulation of Coercive Speech}

This theory of coercive' speech justifies certain aspects of both criminal coercion and blackmail statutes. Other aspects of such statutes, however, go beyond the regulation permitted by the coercive speech theory.

A coercive speech analysis would justify prosecution of a gangster under a criminal coercion statute if the gangster threatened to break a

14 Id. For discussion of coercive speech that targets a listener's legal but illegitimate rights, see Baker, supra note 9, at 999.

15 For a discussion of the benefits of self-expression, see supra note 9. At this point, the analysis in this Comment departs from Professor Baker's. The coercive speech analysis in this text omits a second category of speech included in Professor Baker's analysis. He argues that a "person coercively influences another if . . . she employs means that she had no right to use for changing" the listener's "options (e.g., blackmail)." Id. Professor Baker recognizes, however, that "reliance on law to specify" such means "can be circular." Id. He explains:

Suppose Joe tells [his] Senator that he will continue his protests until the Senator supports the Equal Rights Amendment. To conclude that Joe has coerced the Senator because a law gives the Senator a right to be free from the protests is circular if Joe's protests can be legitimately outlawed only if the protests are coercive. If only coercive aspects of the speech can justify making the speech illegal, the speech's illegality cannot support the view that it is coercive. The prohibition itself cannot justify the prohibition.

Id. at 999-1000. Given this inherent circularity, this Comment adopts the view that the means employed to change a listener's options should be characterized as coercive only if those means can be outlawed on grounds independent of their coercive effect. 
tavern owner's legs unless he voted for a certain political candidate. ${ }^{16}$ The threat forces the tavern owner to choose between two things-the right to be free from physical assault and the right to vote according to individual conscience-when the tavern owner has a legitimate claim to both things. ${ }^{17}$ Likewise the gangster could be prosecuted under a blackmail statute for threatening to break the tavern owner's legs unless he paid the gangster $\$ 200$ per week, for the tavern owner has a right both to his money and to his limbs. ${ }^{18}$ The same analysis would apply in the preceding examples if the gangster's threat had been to destroy the tavern owner's property. ${ }^{10}$ Under the coercive speech analysis, a blackmail or criminal coercion statute is valid to the extent that it proscribes the threat to commit a crime or a tort intended to induce the listener to abandon a legal right. ${ }^{20}$

Coercive speech analysis, however, does not justify blackmail or criminal coercion statutes to the extent that they proscribe threats to commit an act ${ }^{21}$ that is neither a crime nor a tort. ${ }^{22}$ Such threats cannot force the listener to choose between two things, to both of which the listener has a legitimate claim, since the listener has no right to be free from conduct that constitutes neither a crime nor a tort. For example, if a gangster threatens to notify police that a tavern owner illegally serves minors unless the tavern owner votes for a certain political candidate, ${ }^{23}$ or pays the gangster $\$ 200$ per week, ${ }^{24}$ coercive speech analysis does not

1.

16 OR. REv. STAT. § 163.275(1)(a) (1981) proscribes this threat. See supra note

17 Of course, where the threat is to do injury to "some person" other than the listener, it is the right of the third person that would be directly violated by the injury. Still, the listener has a stake in the third person's right; otherwise the speaker would not have made the threat. note 4.

18 Model Penal Code $\S 223.4(1)(a)$ (1980) proscribes this threat. See supra

${ }^{10}$ See, e.g., Or. Rev. Stat. \& 163.275(1)(b) (1981) (criminal coercion), quoted supra note 1; MODEL PENAL CODE § 223.4(1) (1980) (blackmail), quoted supra note 4.

${ }^{20}$ For provisions couched in terms of the criminal nature of the threatened act, see Or. Rev Stat. § 163.275(1)(c) (1981); Model Penal Code § 223.4(1) (1980). In State v. Robertson, 649 P.2d 569, 588-90 (Or. 1982), Judge Linde suggested that even a criminal coercion statute proscribing only threatened crimes or torts would be unconstitutional.

${ }^{21}$ The criminality of the conduct that the threatener induces is irrelevant to this analysis. Noncoercive speech that induces another to commit a crime must be analyzed as solicitation. See Greenawalt, Speech and Crime, 4 Am. B. Found. Research J. 645, 655-70 (1980).

${ }_{23}$ Speech that cannot be restricted as coercive might, of course, be restricted on other grounds-for example, as libelous.

${ }^{23}$ OR. REv. STAT. $\$ 163.275(1)(d)$ (1981) proscribes this conduct. See supra note 4.

24 Model Penal Code $§ 223.4(2)$ (1980) proscribes this conduct. See supra note 
justify prosecution of the gangster. While the tavern owner has a right to vote his conscience and to keep his money, the tavern owner has no right not to be charged accurately with a crime. If such conduct is to be proscribed, something other than coercive speech analysis must provide the justification.

\section{BLACKMaIL}

Unlike criminal coercion statutes, blackmail statutes restrict only commercial speech. ${ }^{25}$ Commercial speech doctrine justifies those restrictions on speech imposed by blackmail statutes but not justified by coercive speech analysis.

\section{A. Blackmail As Commercial Speech}

The United States Supreme Court has always recognized that "[t]here are commonsense differences between speech that does 'no more than propose a commercial transaction,' . . . and other varieties." While criminal coercion statutes reach speech other than commercial speech (because they can be violated when nothing of economic value is at issue), the typical blackmail transaction involves commercial speech.

Recent Supreme Court cases in the commercial speech realm draw a distinction between speech having the purpose of simply increasing the speaker's wealth and speech having an ideological purpose. ${ }^{27}$ The Court has stated that commercial speech is "distinguished by its content." But in distinguishing speech's "content," the Court considers many factors ${ }^{20}$ to determine the purpose of the speech. This becomes clear by comparing two cases that were decided by the Court on the

2. Of course, a criminal coercion statute might be construed as applying to the sort of conduct normally thought of as blackmail. Thus construed, such a statute would be justified by a commercial speech analysis. In this Comment, the potential for this overlap in coverage is ignored to simplify presentation of the argument.

* Virginia Bd. of Pharmacy v. Virginia Citizens Consumer Council, 425 U.S. 748, 771-72 n.24 (1976) (quoting Pittsburgh Press Co. v. Pittsburgh Comm'n on Human Relations, 413 U.S. 376, 385 (1973).

$\approx 2$ A similar distinction has been framed in terms of substantive and instrumental values. See Baker, Commercial Speech: A Problem in the Theory of Freedom, 62 IowA L. REv. 1, 14 (1976). Something valued substantively is valued in and of itself and is not commercial. Something valued instrumentally, like money, is valued instead for something external to itself.

s* Virginia Bd. of Pharmacy v. Virginia Citizens Consumer Council, 425 U.S. 748, 761 (1976).

so Professor Baker discusses a category of commercial speech which is distinguished by its "source." Baker, supra note 27 , at 14 . The source of speech is one factor to consider in determining whether speech has a commercial purpose. 
same day: Ohralik v. Ohio State Bar Association ${ }^{30}$ and In re Primus. ${ }^{21}$ In Ohralik, the Court upheld a prophylactic regulation against in-person solicitation of clients by lawyers "for pecuniary gain." yer in Ohralik had obtained contingent-fee arrangements from two accident victims. In Primus, the Court refused to extend the Ohralik role to a lawyer's soliciting clients on behalf of the ACLU when the solicitation "further[ed] political and ideological goals through associational activity.".83

The Supreme Court considered the totality of the circumstances in both Ohralik and Primus. The Ohralik Court noted that appellant

approached two young accident victims at a time when they were especially incapable of making informed judgments .... He employed a concealed tape recorder, seemingly to insure that he would have evidence of . . . oral assent to the representation. He emphasized that his fee would come out of the recovery, thereby tempting the young women .... . [And he] refused to withdraw when ... requested ... to do so only a day after the initial meeting . . . .

All of this tended to show that "on the facts of this case [appellant] could not contend, that his approaches to the two young women involved political expression or an exercise of associational freedom."2s The purpose of Ohralik's speech was commercial.

The Primus Court, on the other hand, noted that "ACLU sponsorship of litigation" is generally recognized as having the "goal of vindicating civil liberties." of speech that simply 'propose[s] a commercial transaction'" may be inappropriate in "the context of political expression and association." When, as in Primus, an attorney offers free representation in an ideological context, the fact that the ACLU may benefit from courtawarded fees does not lower the "level of constitutional scrutiny."

In Ohralik the purpose of the speech was commercial, and in Primus the purpose was ideological; therefore, the speech in Primus

so 436 U.S. 447 (1978) (disciplinary rule against solicitation of clients upheld as applied to a lawyer soliciting for pecuniary gain).

31436 U.S. 412 (1978) (disciplinary rule against solicitation held invalid as applied to offer of legal services by ACLU lawyer).

22 Ohralik, 436 U.S. at 449.

ss Primus, 436 U.S. at 414.

st Ohralik, 436 U.S. at 467.

ss Id. at 458 (emphasis added).

se Primus, 436 U.S. at 430.

s7 Id. at $437-38$.

ss $7 d$. at 428 . 
received greater protection than the commercial speech in Ohralik. ${ }^{39}$ The Court admits that "[ $\mathrm{t}]$ he line, based in part on the motive of the speaker and the character of the expressive activity, will not always be easy to draw," but it concludes that "that is no reason for avoiding the undertaking." 40

Blackmail falls within the category of speech with a commercial purpose. The essence of the crime is the speaker's demand for something of economic value. A threat demanding nothing, or demanding something of no economic value, is outside the scope of a blackmail statute. Only communications with the purpose of demanding something of economic value are inhibited by blackmail laws. ${ }^{41}$ Blackmail laws are thus subject to analysis under commercial speech doctrine.

\section{B. Proscribing Blackmail}

As commercial speech, blackmail is entitled to less protection than is normally afforded speech. While coercive speech analysis does not justify some provisions of blackmail laws, commercial speech analysis justifies those provisions, giving blackmail statutes a broader permissible scope than criminal coercion statutes. Commercial speech doctrine permits legislatures to proscribe blackmail in which the threatened act itself is neither a crime nor a tort. Legislatures may proscribe blackmail regardless of whether the proposed transaction itself has been outlawed. ${ }^{42}$

39 Justice Rehnquist argues that there is no principled distinction between Primus and Ohralik. He suggests "that the next lawyer in Ohralik's shoes . . . will come here cloaked in the prescribed mantle of 'political association' to assure that insurance companies do not take unfair advantage of policyholders." Id. at 442 (Rehnquist, J., dissenting).

10 Primus, 436 U.S. at 438 n.32 (emphasis added).

11 See, e.g., Model Penal Code $\$ 223.4$ (1980), quoted supra note 4; State v. Felton, 399 So. 2d 797 (La. 1976) (blackmail law violated when threats used to force sexual relations).

12 Commentators have disagreed about whether blackmail transactions should be outlawed. Compare M. Rothbard, 1 MaN, Economy, aNd STATE 443 n.49 (1962) ("blackmail would not be illegal in a free society" because it is "non-violent") and Murphy, Blackmail: A Preliminary Inquiry, 63 MoNist 156, 157-58 (blackmail may be a "non-deviant" economic transaction in a free economy) with R. NozIck, ANARCHY, STATE AND UTOPIA 84-86 (1974) (blackmail is an "unproductive" transaction and has no claim to protection in a libertarian society) and Williams, Blackmail, 1954 CRIM. L. REv. 79, 163 ("two things [which] taken separately are moral and legal whites make a moral and legal black").

Murphy urges consideration of "a whole range of economic transactions" before deciding that blackmail should be outlawed.

Such an examination will have an impact on some deep ideological divisions within social philosophy-e.g., on the conflict between Libertarians (who argue that any economic transaction between consenting adults, in- 


\section{Blackmail Proposing a Prohibited Act}

Blackmail proposes a commercial transaction-for example, the trading of money for an agreement to refrain from certain conduct. States may outlaw such transactions. If they do, then prohibition of blackmail itself is justified under commercial speech doctrine as the prohibition of speech proposing an illegal commercial transaction.

States have broad range to enact economic legislation for the public welfare:

[I] $\mathbf{n}$ the absence of [a specific] constitutional restriction, a state is free to adopt whatever economic policy may.reasonably be deemed to promote public welfare, and to enforce that policy by legislation adapted to its purpose. The courts are without authority either to declare such policy, or, when it is declared by the legislature, to override it. ${ }^{48}$

Thus, a legislative decision to outlaw blackmail transactions, absent any lurking first amendment problem, will be accorded judicial deference.

A complication arises, however, when the blackmailer threatens protected speech as the sanction in the blackmail transaction. This speech differs from speech involved in the offer to engage in a blackmail transaction, which is implicated irrespective of the threatened sanction. When protected speech is part of the transaction itself, on the other hand, the first amendment is implicated on a second level by the proscription of the blackmail transaction. The blackmail threat, "Pay me $\$ 5000$ or I will burn your house down," implicates speech only at the first level. Burning down a house is not speech-related. The blackmail threat, "Pay me $\$ 5000$ or I will reveal information about your sordid past," implicates speech on a second level.

It could be argued that any attempt to outlaw speech-related transactions runs afoul of free speech principles. For example, though legislatures may regulate the sale of milk, ${ }^{44}$ it is quite another thing to prohibit the sale of newspapers. ${ }^{45}$ This argument presumably would

cluding blackmail, should be allowed) and Marxists (who argue that all capitalistic economic transactions should, because they are really blackmail, be prohibited). There is a sense ... in which Libertarians and Marxists agree on something quite basic-namely that the blackmail transaction is a nondeviant transaction within a capitalistic economic system.

Murphy, supra, at 157-58 (footnote omitted).

13 Nebbia v. New York, 291 U.S. 502, 537 (1934) (New York's milk price control regulations upheld).

4t See id.

45 See Baker, Press Rights and Government Power to Structure the Press, $34 \mathrm{U}$. 
prevent proscription of the blackmail transaction when it includes the threat of protected speech.

This argument is invalid for two reasons. First, the sale of newspapers deserves special protection under the first amendment press clause. ${ }^{48}$ Second, the blackmail transaction, unlike the newspaper transaction, does not have a communicative purpose. The blackmailer uses the threat of communication only as a sanction to obtain property. It is irrelevant to the blackmailer whether the communication occurs. The purpose of a blackmail statute is to eliminate this acommunicative transaction. Because legislation with such a purpose is consistent with principles of free speech, blackmail transactions may be proscribed.

If the blackmail transaction is outlawed, precedent indicates that offers to engage in it are unprotected. In Pittsburgh Press Co. v. Pittsburgh Commission on Human Relations, ${ }^{47}$ the Court upheld a city ordinance forbidding sex-designated advertising of jobs for which sex discrimination was prohibited. The Supreme Court held that "[a]ny First Amendment interest which might be served by advertising an ordinary commercial proposal . . . is altogether absent when the commercial activity itself is illegal and the restriction on advertising is incidental to a valid limitation on economic activity."

Whether the underlying commercial transaction proposed by blackmail has been proscribed in a particular jurisdiction is a matter of statutory interpretation. For example, the Model Penal Code provides that "[a] person is guilty of theft if he purposely obtains property of another" by employing threats. ${ }^{49} \mathrm{~A}$ statute in this form outlaws the blackmail transaction. Because the completed transaction violates the commercial proscription, speech proposing the transaction may be restricted under Pittsburgh Press.

MiamI L. Rev. 819 (1980).

4. The Supreme Court has noted that the press merits special protection.

The Constitution specifically selected the press, which includes not only newspapers, books, and magazines, but also humble leaflets and circulars, ... to play an important role in the discussion of public affairs. Thus the press serves and was designed to serve as a powerful antidote to any abuses of power by governmental officials . . . .

Mills v. Alabama, 384 U.S. 214, 219 (1966) (citation omitted) (statute proscribing election-day newspaper editorials concerning candidates or referendums held invalid); see Baker, supra note 45 , at 822-36.

47413 U.S. 376 (1973).

4. Id. at 389 .

- Model Penal Code § 223.4 (1980), quoted supra note 4. 


\section{Blackmail Proposing a Legal Act}

The blackmail laws in some states, however, do not outlaw the proposed commercial transaction. These states "treat as the substantive crime of extortion the making of certain specified threats for the purpose of obtaining property." gal, but the speech involved in the transaction is proscribed. Such blackmail statutes should be upheld.

Although Pittsburgh Press could be read as holding that commercial speech has no speech value, ${ }^{81}$ the Court rejected that view in Virginia State Board of Pharmacy v. Virginia Citizens Consumer Council, Inc., ${ }^{\mathbf{b}}$ holding that consumers have a first amendment right to receive advertising or other affirmative dissemination of prescription drug price information. ${ }^{\text {s8 }}$ Read together, Pittsburgh Press and Virginia Pharmacy establish that commercial speech has a lower-level speech value. The value lies in the possibility that commercial speech will provide listeners with information to assist them in making competitive market decisions. That value is small when the speech informs listeners about illegal transactions, and the state's interest in regulating speech is substantial in this context. In Pittsburgh Press the value of the speech was outweighed by the valid state interest in enforcing its decision to outlaw the commercial transaction. In Virginia Pharmacy, the balance tipped in the other direction. Balancing ${ }^{\text {t4 }}$ is therefore necessary in commercial speech cases. Although commercial speech has speech value, it

so Note, A Rationale of the Law of Aggravated Theft, 54 CoLum. L. REv. 84, 85 (1954) (footnote omitted).

s1 See Jackson \& Jeffries, Commercial Speech: Economic Due Process and the First Amendiment, 65 VA. L. REv. 1, 35 (1979). "If independent first amendment significance did exist in [commercial speech], it would also exist where the state has declared the underlying transaction unlawful." Id.

s2 425 U.S. 748 (1976).

ss Id. at 752 .

Virginia Pharmacy has drawn sharp criticism. There are three main criticisms. First, some critics argue that commercial speech promotes instrumental rather than substantive values. See Baker, supra note 27, at 14. Thus, it "does not promote the underlying values of the system [of free expression] as does other expression." Emerson, First Amendment Doctrine and the Burger Court, 68 GALIF. L. REv. 422, 459-61 (1980). Second, one may contend that the inclusion of commercial speech in the free speech system "tends to dilute and devitalize first amendment doctrine." Id. Finally, some object to Virginia Pharmacy on the ground that it incorporates economic due process into the first amendment. See Virginia Pharmacy, 425 U.S. at 783-84 (Rehnquist, J., dissenting); Jackson \& Jeffries, supra note 51, at 30-31.

If Virginia Pharmacy was wrongly decided-if commercial speech has no speech value-then blackmail proposing a legal transaction could be proscribed without further inquiry.

st See Ely, Flag Desecration, 88 Harv. L. Rev. 1482, 1500-02 (1975); Nimmer, The Right to Speak from Times to Time, 56 CaLIF. L. REv. 935, 938-48 (1968). 
remains unprotected when it has a low value and conflicts with important and valid legislative objectives.

When balancing in the realm of commercial speech, one must remember that Virginia Pharmacy protects the rights of listeners to hear commercial speech. ${ }^{\mathrm{SS}}$ The listener in a blackmail transaction is the person being blackmailed. It is counter-intuitive to talk about the listener's interest in being blackmailed. The listener is the "victim" of blackmail, the party blackmail statutes aim to protect. But the listener may prefer blackmail to its alternative. ${ }^{56}$ Balancing is therefore required to determine the validity of statutes proscribing blackmail that proposes a legal act.

Commercial speech falls into three categories. First, the speech may implicate a nonspeech constitutional right of the listener. Second, the speech may propose a transaction that the legislature would not outlaw totally, though it would have the power to do so. Third, the speech may propose a transaction that the legislature means to outlaw totally but has failed to do directly.

The listener's interest is greatest when the transaction involved in the commercial speech implicates a nonspeech constitutional right of the listener. A woman's right to information about abortion, for example, weighs strongly. On the other side of the balance, the state has no legitimate interest in preventing a woman from exercising her right to abortion by preventing dissemination of relevant information (though it does have a legitimate interest in preventing profiteering).$^{57}$ Where the listener's nonspeech constitutional rights are implicated, commercial speech protection should be at its maximum. ${ }^{58}$ In such a situation, justification or a restriction on speech should be difficult if not impossible.

When the legislature is empowered to outlaw a transaction en-

Bs See supra notes 52-53 and accompanying text; see also Virginia Pharmacy, 425 U.S. at 781 (Stewart, J., concurring) ("the elimination of false and deceptive claims serves to promote the one facet of commercial price and product advertising that warrants First Amendment protection-its contribution to the flow of accurate and reliable information relevant to public and private decisionmaking").

${ }_{58}$ "[I]n many cases the person being blackmailed is willing to pay the asked price, and far prefers paying the price to having the blackmailer expose him .... [t]he 'victim' may well be upset rather than grateful if his blackmailer is successfully prevented from offering him his services ...." Murphy, supra note 42, at 159.

${ }^{67}$ See Bigelow v. Virginia, 421 U.S. 809 (1975). The asserted state interest in "regulating what Virginians may hear or read about the [legal] New York [abortion] services" was held entitled to "little, if any, weight." Id. at 827-28.

58 See Note, Freedom of Expression in a Commercial Context, 78 HaRv. L. REv. 1191,1196 (1965) ("if a government cannot entirely prohibit the sale of a commodity, the first amendment should permit truthful advertising of the commodity if there exist reasonably effective alternative means by which the government could achieve the purposes for which the restriction is imposed"). 
tirely but has decided not to do so, the listener's interest in learning about the transaction may also be reasonably important. If the legislature would not outlaw the transaction because it is generally considered to be beneficial, the listener has a valid claim to information about the product. In Virginia Pharmacy, for example, the state legislature had passed a statute declaring it unprofessional conduct for a licensed pharmacist to advertise the prices of prescription drugs. The legislature had not outlawed the sale of drugs in competing, independent, privately owned drug stores, and therefore, it should not have been permitted to limit commercial speech so as to prevent effective competition. On the other hand, when the transaction is generally considered to be harmful but outlawing the transaction is problematic, limitations on commercial speech may be more appropriate. "Thus, for example, the legislature rationally might conclude that the sale of cigarettes should be allowed but that advertising should be banned to discourage new users."

The listener's interest is lowest when the legislature intended to outlaw the transaction, but the law was not properly framed to do so. ${ }^{60}$ The listener's interest rests solely upon the legislature's failure to accomplish what it intended. That interest seems :slight. Accordingly, commercial speech restrictions in this context should be given broad permissible scope.

Blackmail statutes in states that have failed to outlaw the blackmail transaction fall into the final category. Lawmakers in those states wished to prevent blackmail, and they had the power to do so; their error was in not targeting the transaction. The listener's interest in blackmail speech is accordingly small. First amendment protection for such speech should be at its minimum, and it is outweighed by the state's interest in protecting its constituents from the morally repugnant blackmail transaction.

69 Jackson \& Jeffries, supra note 51, at 35 (footnote omitted); see, e.g., 15 U.S.C. $\S 1335$ (1976) ("it shall be unlawful to advertise cigarettes ... on any medium of electronic communication subject to the jurisdiction of the Federal Communications Commission"); Capital Broadcasting Co. v. Acting Attorney Gen., 405 U.S. 1000 (1972) (15 U.S.C. \& 1335 upheld).

so But see Linde, "Clear and Present Danger" Reexamined: Dissonance in the Brandenburg Concerto, 22 STAN. L. REV. 1163, 1182 (1970). Judge Linde argues that the first amendment requires legislatures to aim at substantive evils, rather than speech.

It is not too much to ask lawmakers, if they believe that hateful expression actually causes identifiable harm, to direct their laws against the causing of such harm (laws which speech . . . may under some circumstances be sufficient to violate), rather than to vent the public indignation by outlawing the expression itself.

Id. 


\section{Conclusion}

Although coercive speech analysis supports the validity of criminal coercion provisions restricting speech that forces a listener's choice between two things to which the listener has a valid claim, it does not support the validity of other criminal coercion provisions. Nor does it support the validity of blackmail provisions corresponding to the latter set of criminal coercion provisions. These blackmail provisions, however, are valid as restrictions on commercial speech. Blackmail laws accordingly have a broader permissible scope than criminal coercion laws. 